\title{
PENINGKATAN KONEKSI MATEMATIS MELALUI PEMBELAJARAN BERBASIS MASALAH DI MAN I MALANG
}

\author{
Siti Inganah, Yus Mochamad Cholily, Marhan Taufik, Siti Khoiruli Ummah \\ FKIP Universitas Muhammadiyah Malang, Indonesia \\ Email: singanah@gmail.com
}

\begin{abstract}
ABSTRAK
Penelitian ini bertujuan untuk mendeskripsikan peningkatan koneksi matematis siswa melalui pembelajaran berbasis masalah. Koneksi matematis merupakan hal yang sangat penting untuk dipelajari pada matematika. Metode penelitian ini menggunakan pendekatan deskriptif dengan data kualitatif. Hal ini ditinjau dari keterlaksanaan pembelajaran berbasis masalah dan indikator peningkatan koneksi matematis. Indikator koneksi matematis yang dimaksud dikembangkan dari tiga aspek antara lain koneksi antar topik matematika, koneksi antar bidang studi matematika, dan koneksi matematika dalam kehidupan sehari-hari. Penelitian dilalukan selama empat kali pertemuan dengan subyek penelitian kelas XI IPA sebanyak 38 siswa dan kelas XI IPS sebanyak 32 siswa di MAN 1 Malang melalui program Lesson Study. Instrumen penelitian berupa catatan lapangan, lembar observasi, dan UKBM yang dibuat guru. Data diperoleh dengan cara mencatat pada lembar catatan lapangan dan lembar observasi dengan bantuan observer. Hasil dari penelitian ini yaitu adanya peningkatan kemampuan koneksi matematis siswa dalam mempelajari materi eksponen dan matriks. Peningkatan ditinjau dari ketidakmampuan siswa menjadi keterampilan menyelesaikan masalah matematika dengan mengaitkan permasalahan dengan materi persamaan kuadrat, persamaan linier, dan persamaan lingkaran dengan kategori sangat baik. Hal ini ditinjau dari analisis hasil pengerjaan soal siswa yang sudah dapat mengkaitkan materi sebelumnya. Contohnya, siswa mampu menentukan akar persamaan kuadrat yang merupakan materi yang telah dipelajari sebelumnya. Akan tetapi, pada indikator koneksi matematis dalam kehidupan sehari-hari, siswa belum dapat menjelaskan adanya keterkaitan materi dalam kehidupan sehari-hari. Hal ini dibuktikan dari siswa yang belum dapat menyelesaikan soal cerita tentang perkembangbiakan bakteri menggunakan materi eksponen.
\end{abstract}

Kata Kunci: Pembelajaran Berbasis Masalah, Koneksi Matematis

\begin{abstract}
This research aimed to describe the increase in students' mathematical connections through problem-based learning. Mathematical connections is important to be learned on mathematics. The methods in this research used a descriptive approach using qualitative data. This reviewed by The Implementation of problem-based learning and the improvement of mathematical connection indicator. Mathematical connections was indicators developed from three aspects, among others, the connection between the topiks of mathematics, the connection between the research of mathematics, and mathematics in everyday life. The research was implemented in four sessions to the subject research of Class XI IPA of 38 students and Class XI IPS of 32 students in MAN 1 Malang through Lesson Study. The research instrument is in the form of the field note, observations sheet, and UKBM made by the teachers. The data were obtained by writing on a field note and observation sheet conducted by the observer. The results of this research were an increase of the ability of students' mathematical connections in learning the material and matrix exponent. The increased in ability of students into math skills to resolve problems by referring problem material with quadratic equations, linear equations, and the equation of the circle with the category. This review of the analysis of the results is taken from the students' work who already can associate the previous material. For example, students were able to determine the root of the quadratic equations which was the material that has been previously studied. However, at the indicator of mathematical connections to everyday life, students were not yet able to explain the existence of entanglement of matter in daily life. This was evidenced from the students who have not been able to solve the question of the story about the breeding of bacteria by using material exponents.
\end{abstract}

Keyword: Problem Based Learning, Mathematical Connection 


\section{PENDAHULUAN}

Matematika merupakan mata pelajaran wajib yang harus dipelajari sejak jenjang sekolah dasar. Pembelajaran matematika pada jenjang sekolah tinggi yaitu SMA mementingkan aspek kognitif yang ditingkatkan baik melalui skill maupun proses (Muller, J., \& Subotzky, 2001) (Mhlolo, Venkat, \& Schfer, 2012) (Zakirova \& Shilova, 2016). Peningkatan tersebut dapat dilakukan dengan cara melibatkan matematika dalam kehidupan seharihari. Adanya keterlibatan matematika dalam kehidupan sehari-hari yang berupa masalah merupakan suatu koneksi matematis. Selama ini, pembelajaran matematika di sekolah menggunakan UKBM (Unit Kegiatan Belajar Mandiri) yang dibuat oleh guru. UKBM mempunyai komponen materi, rangkuman, dan latihan soal. Soal yang termuat pada UKBM telah diselesaikan pada contoh soal sehingga siswa kesulitan dalam menyelesaikan soal yang telah dimodifikasi. Ketika diberikan soal, siswa tidak dapat menjelaskan alasan pengambilan prosedur penyelesaian. Koneksi matematis apabila selalu ditingkatkan dalam pembelajaran matematika dapat membuat siswa memahami dan menguasai permasalahan sosial, ekonomi, dan sains. Guru sebagai fasilitator harus dapat memberikan kesempatan kepada siswa untuk melihat keterkaitan matematika dalam kehidupan sehari-hari kemudian dapat menyelesaikannya (Rohendi \& Dulpaja, 2013). Adanya koneksi matematis tersebut dapat membuat siswa mengingat dan memahami materi karena siswa mengalami bagaimana menyelesaikan permasalahan sehari-hari yang dekat dengan siswa secara matematis
(Dalgleish et al., 2007; Kartikasari A \& D B Widjajanti, 2017; National Council of Teachers of Mathematics (NCTM), n.d.)

Berdasar hasil observasi dan wawancara terhadap guru matematika di MAN I Malang, guru masih belum dapat terbiasa mengaitkan matematika dengan permasalahan sehari-hari. Hanya beberapa bagian dari pembelajaran suatu materi yang dapat dikaitkan dengan permasalahan seharihari. Pembelajaran matematika yang dilakukan biasanya berupa pengerjaan soal matematika yang prosedural dengan satu jawaban benar baik secara individu maupun secara keompok. Pembelajaran matematika yang biasa mengaitkan matematika dengan memunculkan masalah dalam kehidupan sehari-hari yaitu pada materi aritmetika sosial dan program linier. Selain kedua materi tersebut, permasalahan sehari-hari jarang disajikan pada pembelajaran. Siswa juga merasa kesulitan dalam mengkoneksikan matematika dalam kehidupan sehari-hari karena belum terbiasa.

Salah satu metode pembelajaran yang dapat melibatkan masalah dalam kehidupan sehari-hari dalam pembelajaran matematika yaitu pembelajaran berbasis masalah. Pembelajaran berbasis masalah dapat memfasilitasi siswa untuk dapat dekat dengan permasalahan yang nantinya dapat diselesaikan secara matematis (Adzobu, 2014; Digest, Created, Eric, \& Resources, 2003; Jaisook, Chidmongkol, \& Thongthew, 2013; Kartikasari A \& D B Widjajanti, 2017). Pembelajaran berbasis masalah merupakan salah satu bentuk pembelajaran konstruktivis dimana siswa diharapkan dapat mengkonstruk pengetahuan dari materi 
yang dipelajari melalui penyelesaian masalah sehari-hari (Cazzola, 2008). Manfaat pembelajaran berbasis masalah antara lain siswa dapat terlibat atau menciptakan penelitian pada materi yang dipelajari, adanya keterkaitan antara teori dan praktik, dan adanya aplikasi pengetahuan dan skill (Crowley, 2015; Rahadi, 2014; Stylianou, 2013). Hal ini dapat diwujudkan melalui kegiatan penyelesaian masalah.

Pelaksanaan pembelajaran berbasis masalah yaitu siswa diberikan permasalahan yang berkaitan permasalahan yang dekat dengan kehidupan siswa sehari-hari. Siswa kemudian mendiskusikan permasalahan dan menyelesaikannya melalui diskusi kelompok kecil. Diskusi dapat dilakukan dengan cara mengumpulkan informasi dari berbagai sumber misalnya buku, internet maupun sumber belajar lainnya yang relevan untuk menyelesaikan permasalahan. Setelah permasalahan diselesaikan, siswa bersamasama menyimpulkan temuan atau mendiskusikan kesimpulan. Kesimpulan tersebut harus dapat membuat siswa dapat mengaitkan pembelajaran matematika dengan kehidupan seharihari. Melalui diskusi kelompok, siswa dapat membuat atau memunculkan permasalahan baru. Permasalahan baru tersebut dapat diselesaikan kembali menggunakan tahapan pembelajaran yang sama seperti sebelumnya. Hal ini mengakibatkan pembelajaran berbasis masalah tidak berhenti pada satu masalah saja melainkan dapat berlanjut pada permasalahan-permasalahan baru yang muncul sebagai hasil diskusi kelas (Cazzola, 2008; Fauzia, 2018; Ulfa \& Asriana, 2018)

Penyelesaian masalah matematika mampu membuat siswa mengaitkan materi sebelumnya, materi selain matematika, dan kehidupan sehari-hari melalui diskusi dan memberikan makna atau interpretasi terhadap penyelesaian masalah matematika (Padmavathy \& Mareesh.K, 2013).Hal ini yang dijadikan sebagai indikator koneksi matematis. Koneksi matematika dengan materi lain dapat berupa kegiatan review yang mengulas materi prasyarat. Koneksi matematika dengan subjek lain dapat berupa aplikasi penggunaan rumus atau manfaat matematika pada mata pelajaran lainnya. Konkesi matematis dengan kehidupan sehari-hari dapat berupa motivasi atau penggunaan soal yang melibatkan permasalahan seharihari yang dekat atau dimungkinkan untuk dialami siswa.

Pembelajaran berbasis masalah yang mempunyai ciri khusus yaitu disajikannya masalah dalam kehidupan sehari-hari kepada siswa dapat dikaitkan dengan kemampuan koneksi matematis siswa. Siswa dapat menggunakan atau memunculkan ketiga aspek koneksi matematis dalam pembelajaran. Hal ini diharapkan siswa dapat memahami kebermanfaatan matematika dalam kehidupan sehari-hari.

\section{METODE}

Metode penelitian berjenis penelitian deskriptif kualitatif. Hal ini dikarenakan penelitian menggunakan data kualitatif untuk dideskripsikan kembali berdasarkan literatur yang bersesuaian. Data kualitatif yang dimaksud yaitu keterlaksanaan pembelajaran berbasis masalah untuk meningkatkan kemampuan koneksi matematis. Data yang diperoleh berasal dari catatan lapangan dan hasil 
kerja siswa untuk diidentifikasi dan dideksripsikan koneksi matematis yang muncul.

Penelitian dimulai dari koordinasi awal, perijinan ke sekolah hingga pelaksanaan pembelajaran. Penelitian melibatkan dua kelas yang mempunyai jenjang dan peminatan yang berbeda. Untuk mendapatkan dan mengumpulkan data serta informasi yang dibutuhkan sebagai bahan analisis. Langkah kegiatan penelitian selanjutnya adalah Studi Literatur. Studi literatur dilakukan untuk mengkaji lebih lanjut mengenai pembelajaran berbasis masalah dan koneksi matematis. Langkah selanjutnya yaitu perijinan dan pembuatan instrumen observasi. Pada tahap ini, peneliti mendatangi sekolah untuk mengurus perijinan dan melakukan kesepakatan dengan guru mata pelajaran. Kegiatan diskusi dengan guru dilakukan untuk mengetahui karakteristik siswa. Pelaksanaan pembelajaran melibatkan dua guru dan beberapa observer. Pada tahap observasi lapangan, peneliti beserta observer mengamati pembelajaran dan mencatat segala aktivitas siswa disesuaikan dengan tahapan pembelajarn berbasis masalah. Selama pengamatan lapangan, sumber data berupa hasil observasi, catatan lapangan dan dokumentasi yang mendukung untuk menjawab masalah penelitian yang sudah ditetapkan.

Data yang akan diambil pada penelitian ini antara lain (1) hasil pekerjaan siswa secara tertulis, (2) hasil observasi dan suasana kelas selama pembelajaran berlangsung, (3) hasil catatan lapangan dari rangkaian kegiatan pembelajaran, dan (4) hasil perekaman baik berupa foto ataupun video pembelajaran.

\section{HASIL DAN PEMBAHASAN}

Observasi awal dilaksanakan pada Hari Jumat Tanggal 2 Maret 2017. Sebelum observasi awal berlangsung, peneliti meminta ijin untuk mengimplementasikan pengabdian sesuai proposal yang disusun. Pihak sekolah menetapkan 4 pertemuan dan 1 pertemuan untuk koordinasi pembelajaran. Sekolah juga telah menetapkan bahwa kelas yang mengikuti kegiatan Lesson Study (LS) adalah Kelas X dan Kelas XI. Hal ini dikarenakan Kelas XII telah siap mengikuti UN. Peneliti juga menyampaikan bahwa fokus penelitian adalah adanya permasalahan di setiap pertemuan. Guru matematika di MAN 1 Malang berjumlah 9 orang termasuk wakil kepala sekolah dan kepala sekolah. Implementasi penelitian selanjutnya yaitu koordinasi guru dan peneliti di MAN 1 Malang pada Tanggal 7 -13 Maret 2017. Koordinasi dilaksanakan di MAN 1 Malang dengan dihadiri 6 guru dan kepala sekolah. Secara khusus, penjelasan berkaitan dengan sintaks pembelajaran berbasis masalah yang disajikan pada Tabel 4.1.

Kemudian penjelasan tentang pembelajaran yang akan dilaksanakan sebanyak 4 pertemuan. Kegiatan LS disepakati untuk dilaksanakan pada 4 kelas yang berbeda dengan 2 jenjang yang berbeda. Hal ini dilakukan dengan alasan kemenarikan mengamati kelas 
Tabel 1.1 Fase Pembelajaran Berbasis Masalah

\begin{tabular}{|c|c|c|}
\hline Fase & Indikator & Perilaku Guru \\
\hline 1 & Orientasi siswa pada masalah & $\begin{array}{l}\text { Guru menjelaskan tujuan pembelajaran, menjelaskan } \\
\text { logistic yang diperlukan dan memotivasi siswa yang } \\
\text { terlibat pada aktivitas pemecah masalah }\end{array}$ \\
\hline 2 & $\begin{array}{l}\text { Mengorganisasi siswa untuk } \\
\text { belajar }\end{array}$ & $\begin{array}{l}\text { Guru membantu siswa mendefinisikan dan } \\
\text { mengorganisasikan tugas belajar yang berhubungan } \\
\text { dengan masalah tersebut }\end{array}$ \\
\hline 3 & $\begin{array}{l}\text { Membimbing penyelidikan } \\
\text { individual maupun kelompok }\end{array}$ & $\begin{array}{l}\text { Guru mendorong siswa untuk mengumpulkan } \\
\text { informasi yang sesuai, melaksanakan eksperimen } \\
\text { untuk mendapatkan penjelasan dan pemecahan } \\
\text { masalah }\end{array}$ \\
\hline 4 & $\begin{array}{l}\text { Mengembangkan dan } \\
\text { menyajikan hasil kary }\end{array}$ & $\begin{array}{l}\text { Guru membantu siswa dalam merencanakan dan } \\
\text { menyiapkan karya sesuai seperti laporan, dan } \\
\text { membantu mereka untuk berbagai tugas dengan } \\
\text { temannya. }\end{array}$ \\
\hline 5 & $\begin{array}{l}\text { Menganalisis dan } \\
\text { mengevaluasi proses } \\
\text { pemecahan masalah }\end{array}$ & $\begin{array}{l}\text { Membantu siswa untuk melakukan refleksi atau } \\
\text { evaluasi terhadap penyelidikan mereka dan proses } \\
\text { yang mereka gunakan. }\end{array}$ \\
\hline
\end{tabular}

yang berbeda karakternya. Kesepakatan akhir dari penjadwalan LS diperoleh pelaksanaan LS pada minggu pertama Bulan September 2017 di Kelas X MIA.

Secara umum, pelaksanaan pembelajaran pada empat kelas tersebu sama. Guru sudah siap menjadi guru model dalam pembelajaran. Kesiapan guru sangat baik dibuktikan dengan tersusunnya perangkat pembelajaran yang lengkap. Perangkat pembelajaran yang disiapkan guru antara lain RPP, Unit Kegiatan Belajar sebagai LK, teknik evaluasi, tes formatif, dan lembar kegiatan pembelajaran.
Posisi duduk siswa secara umum dapat dilihat pada Gambar 1.2. Posisi duduk tersebut sama dari awal pembelajaran hingga akhir pembelajaran. Kegiatan berkelompok yang dilakuka tidak mengubah posisi duduk melainkan mengubah arah duduk, sehingga dapat berhadapan.

Posisi duduk siswa yaitu diskusi berpasangan satu bangku, dimana teman satu bangku mengerjakan soal yang diberikan oleh guru secara bersamaan (berdiskusi) mengenai materi pertidaksamaan eksponensial. Siswa dapat merespon materi pembelajaran

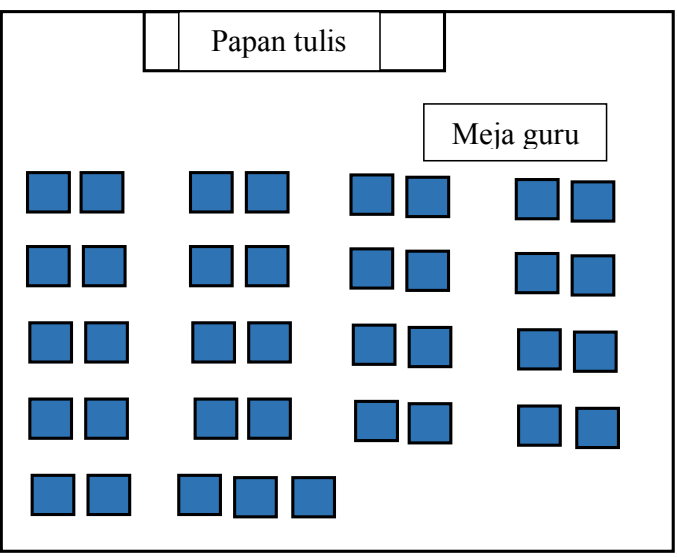

Gambar 1.2 Posisi Duduk Siswa 
dengan baik, dapat menjawab pertanyaan mengenai konsep dasar eksponensial dan konsep dasar pertidaksamaan yang ditanyakan oleh guru.

Secara umum, guru memberikan aspersepsi berupa mereview materi sebelumnya. Kemudian siswa memberikan respon yang baik. Setelah itu, guru menjelaskan konsep dasar tentang pertidaksamaan dan memberikan lembar soal secara berkelompok. Soal berisi lima nomor, yaitu "Ayo Berlatih Satu" sejumlah dua soal dan "Ayo Berlatih Dua" sejumlah tiga soal. Setiap soal diberikan waktu 3 menit untuk mengerjakannya. Siswa berkelompok beranggotakan dua anak untuk memahami dan mengerjakan soal. Selanjutnya, siswa menuliskan jawaban soal di papan tulis. Guru dan murid membahas hasil pengerjaan tersebut.

Pelaksanaan pembelajaran berbasis masalah sudah sejalan dengan tahapan pembelajaran berbasis masalah yang dikemukakan penelitian terdahulu. Tahapan yang dilakukan yaitu penyajian masalah, penyelesaian masalah secara berkelompok dan memuncukan permasalahan baru dari hasil diskusi (Cazzola, 2008; Rahadi, 2014). Perbedaannya, penelitian ini tidak dapat memunculkan permasalahan baru dikarenakan waktu kegiatan review pembelajaran tidak dapat dilaksanakan di kelas.

1. Kemampuan koneksi matematis antar topik matematika

Pertemuan pertama di Kelas X MIA 1 menunjukkan koneksi matematis siswa Kelas X MIA 1 belum muncul. Hal ini ditunjukkan siswa belum mampu mengkoneksikan materi prasyarat dari pertidaksamaan eksponen yaitu pertidaksamaan bilangan bulat. Siswa seringkali lupa bahwa perubahan tanda pertidaksamaan terjadi apabila dikalikan dengan bilangan negatif Pertemuan kedua sudah memunculkan koneksi antar topik matematika yaitu memberikan atau menjelaskan materi prasyarat berupa pertidaksamaan bilangan bulat di awal pembelajaran sehingga siswa mudah mengingatnya.

Pertemuan ketiga di Kelas XI IPS 2 menunjukkan koneksi matematis juga belum muncul. Materi yang diajarkan yaitu operasi matriks. Penyajian hasil kemampuan siswa dilakukan dengan cara diskusi berkelompok untuk menyelesaikan UKBM. UKBM dibuat oleh guru. Setelah diskusi berakhir, guru menunjuk perwakilan dari masing-masing kelompok untuk mempresentasikan dengan cara menuliskan hasil diskusi kelompok di papan tulis. Ada tiga siswa yang belum mampu menjelaskan hasil diskusi di papan tulis. Pada operasi matriks ini, siswa yang seluruhnya berjenis kelamin laki-laki belum mampu mengoperasikan bilangan bulat positif dan negatif. Selain itu, siswa masih terlihat kebingungan dalam mengoperasikan matriks sesuai posisi elemen-elemennya. Sifat operasi dasar bilangan bulat berupa distributif, komutatif, dan asosiatif belum dapat dikuasai siswa. Siswa mengaku lupa dengan perbedaan sifat-sifat tersebut. Pertemuan selanjutnya, guru telah melakukan tanya jawab tentang materi prasyarat yaitu operasi bilangan bulat dan sifat operasi dasar bilangan bulat. Siswa diminta untuk menunjukkan sifat operasi dasar mana saja yang dapat berlaku pada operasi matriks. Karena guru telah melakukan review materi prasyarat, siswa merasa mudah dalam menyelesaikan permasalahan yang diberikan guru. 
Temuan penelitian ini sejalan dengan penelitian (Zakirova \& Shilova, 2016) bahwa koneksi matematis dapat dengan mudah muncul pada antar topik matematika itu sendiri.

2. Koneksi matematika dengan mata pelajaran lainnya

Koneksi matematika dengan mata pelajaran lainnya belum muncul selama empat pertemuan. Guru dan siswa merasa kesulitan dalam merumuskan permasalahan yang dapat dikaitkan dengan mata pelajaran lainnya. Kesulitan dari siswa yaitu belum dapat mengoperasikan bilangan bulat dengan melibatkan bilangan negatif pada penyelesaian perkalian matriks berordo $2 \times 2$. Selain itu, siswa juga kurang mampu dalam mendeskripsikan aplikasi matriks pada bidang studi lainnya. Berdasar wawancara dengan guru, guru merasa kesulitan karena materi yang diajarkan bersifat abstrak dan jarang ditemui dalam mata pelajaran lainnya dari segi kebermanfaatannya. Pada saat kegiatan See dari serangkaian kegiatan Lesson Study berlangsung, guru dibangkitkan pengetahuannya tentang keterkaitan materi matriks dan eksponen dengan topik matematika lannya. Misalnya, untuk menyelesaikan persamaan eksponen $3^{x+2}=27^{\times 2}$. Menurut guru dan siswa, yang diperlukan untuk menyelesaikan persamaan yaitu sifat eksponen dan logaritma $\log _{3} 3^{x+2}=$ $\log _{3} 3^{\times 2}$. Hal ini belum dipahami guru pada penyelesaian selanjutnya yaitu persamaan kuadrat. Guru kemudian dapat menjelaskan bahwa topik matematika selanjutnya yaitu penyelesaian persamaan kuadrat dengan cara pemfaktoran. Keterkaitan pada bidang studi lainnya akhirnya muncul dari kecepatan perkembangbiakan bakteri menggunakan persamaan yang melibatkan satuan waktu sehingga memerlukan persamaan kuadrat dan persamaan eksponen untuk diselesaikan. Pada amteri matriks, guru pada akhirnya mampu menjelaskan kegunaan dari matriks yaitu untuk mengkonstruksi portal dan monitoring proyek pada bidang teknik sipil.

3. Koneksi matematika dengan kehidupan sehari-hari

Koneksi matematis antara matematika dengan kehidupan seharihari belum muncul karena siswa dan guru belum dapat membuat aplikasi penggunaan eksponen dan matriks pada kehidupan sehari-hari. Hal in terjadi pada pertemuan pertama sampai ketiga. Namun pada pertemuan keempat guru mensimulasikan matriks sebagai dua kelompok yang beranggotakan empat dnegan posisi duduk yang sama. Kemudian guru mensimulasikan bagaimana memasangkan anggota kelompok apabila jumlah anggota kelompoknya berbeda. Hal ini digunakan untuk mengilustrasikan kesamaan ordo untuk mengoperasikan elemen matriks. Siswa dapat dengan mudah menyimpulkan syarat matriks yang dapat dioperasikan.

\section{SIMPULAN}

Pembelajaran berbasis masalah dapat meningkatkan koneksi matematis siswa. Di awal pembelajaran, guru langsung memberikan masalah berupa aplikasi eksponen dalam kehidupan sehari-hari yaitu perkembangbiakan bakteri. Setelah itu, siswa diberikan UKBM untuk diselesaikan secara berkelompok. Setelah diskusi kelompok dilakukan, masing-masing perwakilan kelompok menuliskan hasil jawaban 
diskusikelompokdanmempresentasikan hasil diskusi kelompoknya. Koneksi matematis yang muncul yaitu koneksi antar topik matematika yaitu berupa pemberian materi prasyarat melalui tanya jawab dan diskusi kelas, Koneksi antar topik matematika yang muncul yaitu materi matriks dengan operasi bilangan bulat. Selain itu, koneksi antar topik matematika yang muncul yaitu antara materi eksponen dengan persamaan kuadrat. Koneksi matematika dengan mata pelajaran lainnya belum muncul selama empat pertemuan. Koneksi matematika dengan kehidupan sehari-hari muncul di akhir pembelajaran sebagai akibat dari munculnya permasalahan dari siswa terkait ordo matriks. Wujud koneksi matematis dengan kehidupan seharihari berupa kegiatan simulasi atau pemberian contoh berupa posisi duduk pada bioskop.

\section{DAFTAR PUSTAKA}

Adzobu, N. (2014). Design, Use and Evaluation of E-Learning Platforms: Experiences and Perspectives of a Practitioner from the Developing World Studying in the Developed World. Informatics, 1(2), 147-159. https://doi. org/10.3390/informatics 1020147

Cazzola, M. (2008). Problem-based learning and Mathematics: Possible Synergical Actions. Proceeding, IATED (International Association of Technology, Education and Development), Valencia, Spain, 2008, 2008. https://doi.org/ISBN: 978- 84-6125091-2

Crowley, B. M. (2015). The Effects of Problem-Based Learning on Mathematics Achievement of
Elementary Students Across Time. Masters Theses \& Specialist Projects.

Dalgleish, T., Williams, J. M. G. ., Golden, A.-M. J., Perkins, N., Barrett, L. F., Barnard, P. J., ... Watkins, E. (2007). [ No Title ]. Journal of Experimental Psychology: General (Vol. 136).

Digest, T., Created, W. A. S., Eric, B. Y., \& Resources, T. H. E. E. (2003). Learning in Mathematics . ERIC Digest . Problem-Based Learning in Mathematics . ERIC Digest . Learning, 1-7. https://doi.org/ ED482725

Fauzia, H. A. (2018). Penerapan Model Pembelajaran Problem Based Learning Untuk Meningkatkan Hasil Belajar Matematika SD Hadist Awalia Fauzia. Jurnal Primary, 7(April), 40-47.

Jaisook, S., Chidmongkol, S., \& Thongthew, S. (2013). the Development of Instructional Model By Integrating ProblemBased Learning and Collaborative Learning Approach To Enhance Mathematical Problem Solving, Communication and Connection Abilities. 7th International Technology, Education and Development Conference, 13(2), 3196-3204. Retrieved from $\% 7 \mathrm{~B} \% 3 \mathrm{C} \% 7 \mathrm{DGo} \% 5 \mathrm{Cnto}$

Kartikasari A \& D B Widjajanti. (2017). Morphological effect of the type, concentration and etching time of acid solutions on enamel and dentin surfaces. Brazilian Dental Journal, 9(1), 3-10. https://doi.org/10.1088/17426596/755/1/011001 
Mhlolo, M. K., Venkat, H., \& Schfer, M. (2012). The nature and quality of the mathematical connections teachers make. Pythagoras, 33(1), 1-9. https://doi.org/10.4102/ pythagoras.v33i1.22

Muller, J., \& Subotzky, G. (2001). What knowledge is needed in the new millennium?Organization. SAGE Journals, 8(2), 163-182.

National Council of Teachers of Mathematics (NCTM). (n.d.). Six Principles for School Mathematics: Executive Summary. https://doi. org/10.1111/j.1949-8594.2001. tb17957.x

Padmavathy, R. D., \& Mareesh.K. (2013). Effectiveness of Problem Based Learning In Mathematics. International Multidisciplinary E-Journal, 2(I), 45-51.

Rahadi, M. (2014). Mosharafa Jurnal Pendidikan Matematika Volume 3, Nomor 3, September 2014, 3(September), 143-150.

Rohendi, D., \& Dulpaja, J. (2013). Connected Mathematics Project (CMP) Model Based on Presentation Media to the Mathematical Connection Ability of Junior High School Student. Journal of Education and Practicetice, 4(4), 17-22.
Stylianou, D. A. (2013). An Examination of Connections in Mathematical Processes in Students' Problem Solving: Connections between Representing and Justifying. Journal of Education and Learning, 2(2), 23-35. https://doi. org $/ 10.5539 /$ jel.v2n2p23

Sumarji.(2009).PenerapanPembelajaran Model Problem-based Learning untuk Meningkatkan Motivasi dan Kemampuan Pemecahan Masalah Ilmu Statika dan Tegangan di SMK, 32(2).

Ulfa, F. M., \& Asriana, M. (2018). Keefektifan Model PBL dengan Pendekatan Open-ended pada Pencapaian Kemampuan Berpikir Kreatif Matematis dan Disposisi Matematis Siswa, 1, 289-298. https://doi.org/10.1111/j.16000579.2004.00348.x

Zakirova, V. G., \& Shilova, Z. V. (2016). Integrative connection of mathematics and economics. Mathematics Education, 11(8), 3021-3036. 